\title{
An Efficient Novel Acetate Anion Receptor based on Isatin
}

\author{
Hongyan Su, Jianwei Li, ${ }^{a}$ Hai Lin $^{b}$ and Huakuan Lin ${ }^{*, a}$ \\ ${ }^{a}$ Department of Chemistry, Nankai University, Tianjin 300071, China \\ ${ }^{b}$ Education Ministry Key Laboratory of Functional Polymer Materials, Nankai University, Tianjin \\ 300071, China
}

\begin{abstract}
Um receptor para reconhecimento de ânions derivado da tiouréia foi sintetizado combinandose indolina-2,3-diona e 1,3-diaminotiouréia. A interação pode ser facilmente monitorada acompanhando-se as mudanças no espectro de absorção na região do UV-vis induzidas pela complexação de um dado ânion. Por exemplo, verificou-se que o fluoreto liga-se ao receptor na proporção de 1:2, mas esta muda para 1:1 no caso dos ânions di-hidrogenofosfato e acetato. Este último apresenta a maior constante de afinidade dentre eles indicando um melhor reconhecimento molecular pelo novo receptor. Finalmente, a natureza da interação entre o novo receptor e o ânion acetato foram explorados utilizando-se espectroscopia de ${ }^{1} \mathrm{H}-\mathrm{RMN}$.
\end{abstract}

An anion recognition receptor, a kind of thiourea derivative, was designed and synthesized by combining indoline-2,3-dione and 1,3-diaminothiourea. The anion recognition can be easily monitored by anion complexation induced changes in UV-vis absorption spectra. In particular, the binding ratio between the receptor and fluoride is 1:2 but in the case of dihydrogenphosphate and acetate are 1:1. Moreover, the affinity constants revealed that the receptor can recognize acetate well. Finally, ${ }^{1} \mathrm{H}$ NMR experiments were carried out to explore the nature of interaction between this new receptor and acetate.

Keywords: thiourea; anion receptor; optical recognition; acetate

\section{Introduction}

Anions play significant roles in life processes and in the environment, such that the development of new anion receptors is of great interest and significance in host-guest chemistry. ${ }^{1}$ Anion artificial receptor has represented an unique application prospect in anion sensor, ${ }^{2}$ membrane transmit carrier ${ }^{3}$ and simulation, enzyme catalyst synthesis, etc. ${ }^{4,5}$ Also their effects as environmental pollutants have only recently been realized and several types of synthetic chemosensors have been developed to date. For the molecular design of the chemosensors, how to achieve the specific recognition of a certain anion and how to convert the recognition event into a signal are the key points. ${ }^{6}$

Among the various important anionic analytes, biologically important acetate anion is one of the most significant due to its specific biochemical functions in the enzymes and antibodies. ${ }^{7}$ Acetate has unique chemical properties and can form the strongest hydrogen-bond

*e-mail: hklin@nankai.edu.cn interaction with hydrogen-bond donors because of the trigonal geometry and the high basicity. Many examples are available on selective receptor molecules for acetate anion. ${ }^{8-10}$ However, there is paucity of reports that describe the change in color in the visible region of the spectrum, and thereby allowing the visual detection of the acetate anion using a receptor. Accordingly, we designed and synthesized the new receptor 1 (Scheme 1) containing indoline-2,3-dione and 1,3-diaminothiourea subunits. UV-Vis spectral and ${ }^{1} \mathrm{H}$ NMR titration experiments were employed to investigate the interaction between receptor $\mathbf{1}$ and several anions.

\section{Experiments}

\section{Reagents}

Unless otherwise specified, all reagents used in the synthesis were obtained commercially and were used without further purification. All anions used in the titration experiments were added in the form of tetra- $n$-butylammonium (TBA) salts, which were purchased 
<smiles>NNC(=S)NN</smiles>

Scheme 1. The synthetic route of the receptor 1 . from Sigma-Aldrich Chemical Co., stored under vacuum in a dessiccator containing self-indicating silica-gel and fully dried before use. DMSO (dimethyl sulfoxide) was dried over $\mathrm{CaH}_{2}$ and then distilled at reduced pressure.

\section{Apparatus}

${ }^{1} \mathrm{H}$ NMR spectra were obtained in a Varian UNITY Plus$400 \mathrm{MHz}$ Spectrometer using tetramethylsilane (TMS) as an internal reference. SI-MS experiments were performed in a MARINER apparatus. C, H, N elemental analyses were carried out in an Elementar Vario EL. UV-vis spectra were recorded in a Shimadzu UV-2450 Spectrophotometer using a quartz cuvette (path length $=1 \mathrm{~cm}$ ).

\section{General method}

All experiments were carried out at $298 \mathrm{~K}$, unless otherwise mentioned. A $2.0 \times 10^{-4} \mathrm{~mol} \mathrm{~L}^{-1}$ solution of the compound 1 in DMSO was prepared and stored in dry atmosphere. This freshly prepared stock solution was used in all spectroscopic studies after appropriate dilution. $1.0 \times 10^{-2} \mathrm{~mol} \mathrm{~L}^{-1}$ solutions of tetra-n-butylammonium (TBA) salts of the respective anions were prepared using dried and distilled DMSO and were appropriately stored in dry atmosphere.

${ }^{1} \mathrm{H}$ NMR titration experiments were carried out in DMSO- $d_{6}$ solution (TMS as internal reference). Receptor $1(0.91 \mathrm{mg})$ was dissolved in DMSO- $d_{6}$ to obtain a $5 \times 10^{-3} \mathrm{~mol} \mathrm{~L}^{-1}$ solution. Then, increasing amounts of acetate anion (in DMSO- $d_{6}$ ) were added into that solution, and the host-guest interaction was monitored by ${ }^{1} \mathrm{H}$ NMR spectroscopy.

Synthesis of $N, N^{\prime}$-di-(indolino-2-one-3-yl)-1,3diiminothiourea $(\mathbf{1})^{11}$

A solution of indoline-2,3-dione (isatin) (588 mg, $4 \mathrm{mmol})$ in ethanol $(20 \mathrm{~mL})$ was added dropwise to a hot solution of 1,3-diaminothiourea (212 $\mathrm{mg}, 2 \mathrm{mmol}$ ) in ethanol/water $(20 \mathrm{~mL}, \mathrm{v} / \mathrm{v}=1 / 1)$ with stirring at reflux. After being stirred for $5 \mathrm{~h}$, the solvent was removed in a flash evaporator. Recrystallization from ethanol yielded $664 \mathrm{mg}$ of yellow crystals $(83 \%) .{ }^{1} \mathrm{H}$ NMR $(400 \mathrm{MHz}$, DMSO- $d_{6}, \mathrm{Me}_{4} \mathrm{Si}$ ): 14.95 (s, 2H, N-H), 11.34 (s, 2H, S=C-
N-H), 7.58 (d, 2H, Ar-H, J 7.8 Hz), 7.43 (d, 2H, Ar-H, J $7.6 \mathrm{~Hz}), 7.25$ (d, 2H, Ar-H, J 7.6 Hz), 6.97 (d, 2H, Ar-H, $J 8.2 \mathrm{~Hz}$ ). Elemental analysis: Calc. for $\mathrm{C}_{17} \mathrm{H}_{12} \mathrm{~N}_{6} \mathrm{O}_{2} \mathrm{~S}: \mathrm{C}$, 56.04; H, 3.32; N, 23.06; Found: C, 56.25; H, 3.37; N, 23.23. ESI-MS (m/z): $400.10(\mathrm{M}+\mathrm{H}$, calcd. 400).

\section{Results and Discussion}

\section{$U V$-vis spectroscopic measurement}

Firstly, to evaluate the binding ability, UV-vis titration experiments were carried out using a solution of the receptor 1 in dry DMSO tetrabutylammonium salts of $\mathrm{AcO}^{-}, \mathrm{F}^{-}, \mathrm{H}_{2} \mathrm{PO}_{4}^{-}$, $\mathrm{Cl}^{-}, \mathrm{Br}^{-}$and $\mathrm{I}^{-}$, at $298.2 \pm 0.1 \mathrm{~K}$. The set of $\mathrm{UV}$-vis spectra of 1 $\left(1.0 \times 10^{-5} \mathrm{~mol} \mathrm{~L}^{-1}\right)$ recorded upon the addition of increasing concentration of $\mathrm{AcO}^{-}$is shown in Figure 1a. Two bands, one at 380 and another at $490 \mathrm{~nm}$ can be easily identified in the spectrum of the pure solution of $\mathbf{1}$. Upon addition of $\mathrm{AcO}^{-}$, there is an decrease of the $380 \mathrm{~nm}$ band intensity, while the lower energy band intensity increased gradually as a function of acetate concentration, generating an isosbestic point at $404 \mathrm{~nm}$. As a consequence, the color of the solution changed from yellow to red, which could provide a convenient method for naked-eye detection of $\mathrm{AcO}^{-}$, as it was coordinated to $\mathbf{1}$ and the negative charge was dispersed to the $\pi$-conjugated system through intramolecular charge transfer (ICT) effect. A similar spectral change was observed upon the addition of $\mathrm{H}_{2} \mathrm{PO}_{4}^{-}$but the change was smaller. However, as $\mathrm{Cl}^{-}, \mathrm{Br}-$ and $\mathrm{I}^{-}$were titrated into $\mathbf{1}$, the spectra hardly changed even after an excess of the anions were added. In the case of $\mathrm{F}^{-}$, spectra changed without clear isosbestic points (see Figure 1b) implying formation of higher order complexes such as $1 / \mathrm{F}^{-}=1 / 2,{ }^{12}$ in analogy to the formation of $\left[\mathrm{HF}_{2}\right]$ - species. ${ }^{13-14}$ This should be the result of the too small size of $\mathrm{F}^{-}$anion.

Continuous variation method was used to determine the stoichiometric ratios of the receptors to the anion guests. In Figure 2 Job plot ${ }^{15,16}$ of receptor 1 and $\mathrm{AcO}^{-}$in DMSO shows the maximum at a mole fraction of 0.5 . This result indicates that the receptor 1 binds $\mathrm{AcO}^{-}$guest with a 1:1 ratio. Moreover, similar results can also be obtained for $\mathrm{H}_{2} \mathrm{PO}_{4}^{-}$. On the other hand, the Job plot reveals that $\mathbf{1}$ coordinated $\mathrm{F}^{-}$with a 1:2 ratio, showing the maximum at a molar fraction of 0.67 . 

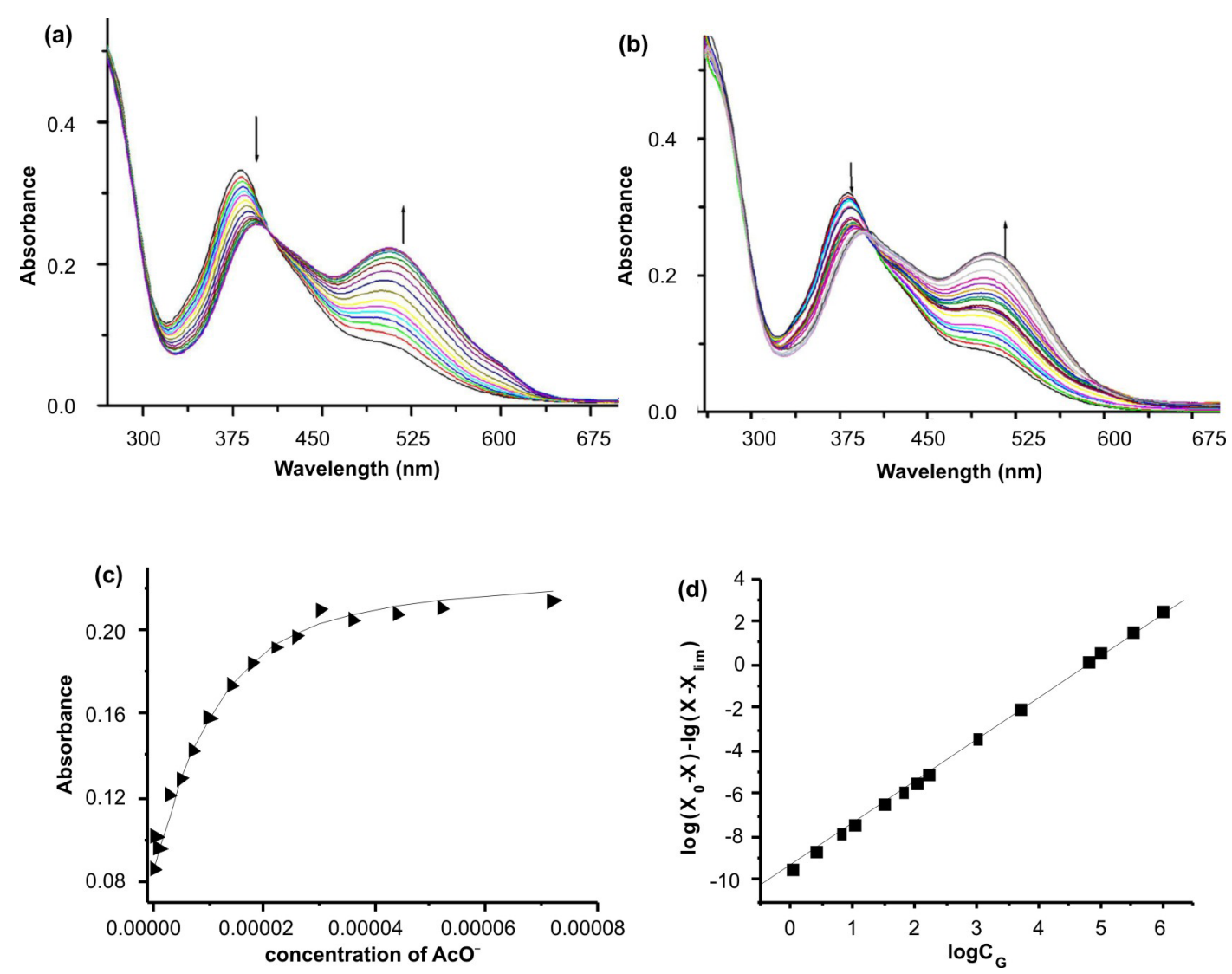

Figure 1. (a). Family of spectra taken in the course of the titration of a $1.0 \times 10^{-5} \mathrm{~mol} \mathrm{~L}^{-1}$ solution of 1 with a standard solution of $\mathrm{AcO}^{-}$at $298.2 \pm 0.1 \mathrm{~K}^{-}$ (b) Family of spectra taken in the course of the titration of a $1.0 \times 10^{-5} \mathrm{~mol} \mathrm{~L}^{-1}$ solution of $\mathbf{1}$ with a standard solution of $\mathrm{F}^{-}$at $298.2 \pm 0.1 \mathrm{~K}$. (c) Fitting curve of the titration of a $1.0 \times 10^{-5} \mathrm{~mol} \mathrm{~L}^{-1}$ solution of 1 with a standard solution of $\mathrm{AcO}^{-}$at $298.2 \pm 0.1 \mathrm{~K}$. (d) Fitting curve of the titration of a $1.0 \times 10^{-5} \mathrm{~mol} \mathrm{~L}^{-1}$ solution of 1 with a standard solution of $\mathrm{F}^{-}$at $298.2 \pm 0.1 \mathrm{~K}$.

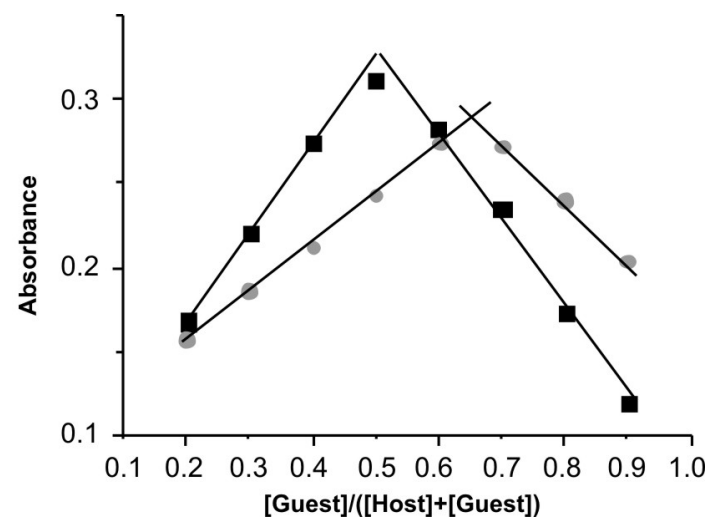

Figure 2. Job plots for complexation of receptor $\mathbf{1}$ with $\mathrm{AcO}^{-}(\boldsymbol{\square})$ or $\mathrm{F}^{-}(\bullet)$ determined by UV-vis spectrophotometry in DMSO at $298.2 \pm$ $0.1 \mathrm{~K},[\mathbf{1}]+[$ anion $]=2.0 \times 10^{-5} \mathrm{~mol} \mathrm{~L}^{-1}$.

For a complex of 1:1 stoichiometry, the relation in Equation (1) could be derived easily, where $\mathrm{X}$ is the absorption intensity, and $C_{\mathrm{H}}$ or $C_{\mathrm{G}}$ is the concentration of the host or the anion guest correspondingly. ${ }^{17}$

$$
\begin{aligned}
X=X_{0}+\left(X_{\lim }-X_{0}\right)\left\{C_{\mathrm{H}}+C_{\mathrm{G}}+1 / K_{\text {ass }}-\left[C_{\mathrm{H}}+C_{\mathrm{G}}+1 / K_{\text {ass }}\right)^{2}\right. \\
\left.\left.\quad-4 C_{\mathrm{H}} C_{\mathrm{G}}\right]^{1 / 2}\right\} / 2 C_{\mathrm{H}}
\end{aligned}
$$

For a complex of 1:2 stoichiometry, the relation in Equation (2) could be derived easily, where $\mathrm{X}$ is the absorption intensity, and $C_{\mathrm{H}}$ or $C_{\mathrm{G}}$ is the concentration of the host or the anion guest correspondingly. ${ }^{18}$

$$
\frac{X_{0}-X}{X-X \text { lim }}=\left(\frac{C_{G}}{K_{\text {ass }}}\right)^{2}
$$

The affinity constants of receptor $\mathbf{1}$ for anionic species were calculated and listed in Table 1 below.

Obviously, the recognition function of $\mathbf{1}$ for $\mathrm{AcO}^{-}$is more remarkable than $\mathrm{H}_{2} \mathrm{PO}_{4}^{-}$. Because $\mathrm{AcO}^{-}$is a trigonal planar species and the angle of O-C-O is about $120^{\circ}$ while the angle of O-P-O is about $108^{\circ},{ }^{19}$ the distance between two oxygen atoms in $\mathrm{AcO}^{-}$might fit better to the recognition sites forming stronger hydrogen bonds. Furthermore, $\mathrm{AcO}^{-}$is a stronger base than $\mathrm{H}_{2} \mathrm{PO}_{4}^{-}$and $\mathrm{F}^{-}$. The affinity constants of $\mathrm{Cl}^{-}, \mathrm{Br}^{-}$and $\mathrm{I}^{-}$for $\mathbf{1}$ were so small probably due to the much lower basicity of those species.

As a validation to the titration experiments, selective recognition experiments were performed by UV-vis spectral investigation. One equivalent of the $\mathrm{AcO}^{-}, \mathrm{H}_{2} \mathrm{PO}_{4}^{-}, \mathrm{F}^{-}$, 
Table 1. Affinity constants of receptor 1 with anions at $298.2 \pm 0.1 \mathrm{~K}$ in DMSO

\begin{tabular}{lcccccc}
\hline Anion & $\mathrm{AcO}^{-}$ & $\mathrm{F}^{-}$ & $\mathrm{H}_{2} \mathrm{PO}_{4}^{-}$ & $\mathrm{Cl}^{-}$ & $\mathrm{Br}^{-}$ & \\
\hline $\operatorname{logKass}$ & $5.38 \pm 0.27$ & $4.73 \pm 0.16$ & $4.46 \pm 0.12$ & $\mathrm{ND}$ & $\mathrm{ND}$ & \\
\hline
\end{tabular}

$\mathrm{ND}=$ can not be determined<smiles>O=C1Nc2ccccc2/C1=N/NC(=S)N/N=C1\C(=O)Nc2ccccc21</smiles>
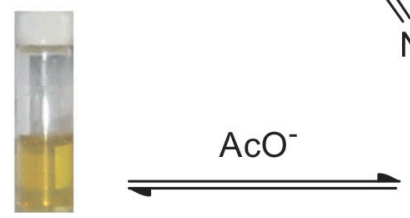<smiles>C=Nc1c(OC)[nH]c2ccccc12</smiles><smiles></smiles>

Scheme 2. The proposed binding mode of $\mathrm{AcO}^{-}$in $\mathbf{1}$.

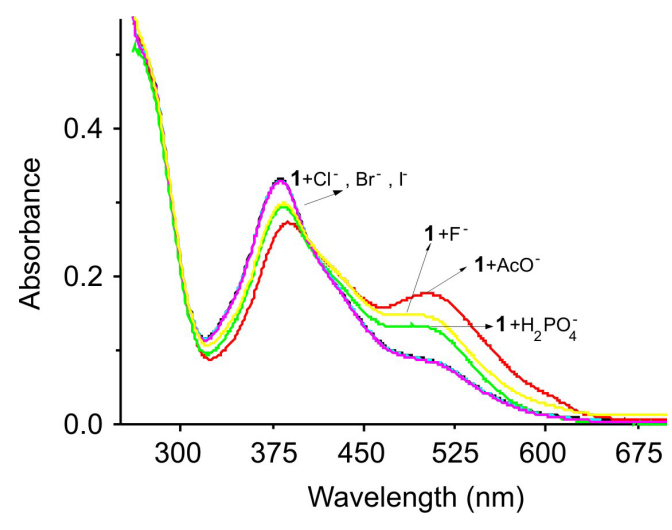

Figure 3. UV-vis spectral changes of $\mathbf{1}$ in DMSO solution $\left(1.0 \times 10^{-5} \mathrm{~mol} \mathrm{~L}^{-1}\right)$ after the addition of 1 equivalent of $\mathrm{AcO}^{-}, \mathrm{H}_{2} \mathrm{PO}_{4}^{-}$, $\mathrm{F}^{-}, \mathrm{Cl}^{-}, \mathrm{Br}^{-}$and $\mathrm{I}^{-}$.

$\mathrm{Cl}^{-}, \mathrm{Br}^{-}$and $\mathrm{I}^{-}$anions, were added to the solution of $\mathbf{1}$ $\left(1.0 \times 10^{-5} \mathrm{~mol} \mathrm{~L}^{-1}\right)$, respectively. The UV-vis spectra were recorded and the results presented that $\mathbf{1}$ could recognize $\mathrm{AcO}^{-}$well (Figure 3).

\section{${ }^{1} \mathrm{H}$ NMR spectroscopic analyses}

Further supporting for the notion that hydrogen bond formed between 1 and anions came from ${ }^{1} \mathrm{H}$ NMR spectroscopic analyses. They were carried out in DMSO-d under normal conditions of so-called NMR titration where the spectra of the receptor $\mathbf{1}$ were recorded in the presence of increasing concentrations of anions (Figure 4). Upon the addition of $\mathrm{AcO}^{-}$to the solution of $\mathbf{1}$, the original peak of $\mathrm{H}_{\mathrm{a}}$ (marked in Scheme 1) at 14.95 ppm disappeared, but that at $11.34 \mathrm{ppm}$ assigned to $\mathrm{H}_{\mathrm{b}}$ (marked in Scheme 1) shifted downfield. When 1.5 equivalents of $\mathrm{AcO}^{-}$were added to $\mathbf{1}$, the peaks corresponding to $\mathrm{H}_{\mathrm{b}}$ broadened and moved downfield to $12.64 \mathrm{ppm}(\Delta \delta=1.30 \mathrm{ppm})$, which suggests that $\mathrm{AcO}^{-}$was being combined with the two $\mathrm{H}_{\mathrm{b}}$ of receptor
1 by hydrogen bonding. However, on the one hand, as to the signals of $\mathrm{H}_{\mathrm{a}}$, they were still not observed in the whole titration process of $\mathrm{AcO}^{-}$anions. On the other hand, the signals of the phenyl group shifted upfield, which indicated the increase of the electron density on the phenyl ring owing to the deprotonation taking place. As a function of the titration experiments and spectra analysis, the proposed binding mode of receptor $\mathbf{1}$ and $\mathrm{AcO}^{-}$is given in Scheme 2. ${ }^{12}$

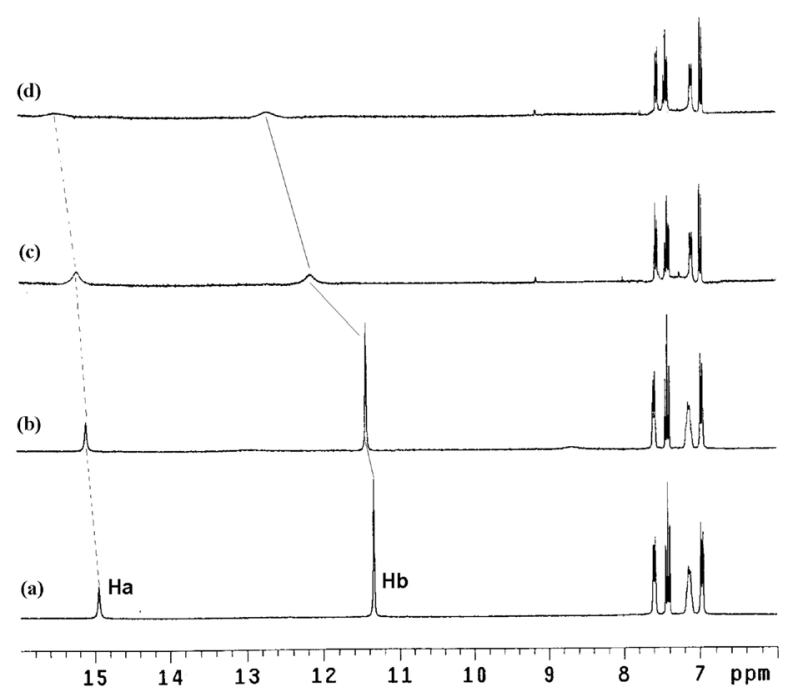

Figure 4. ${ }^{1} \mathrm{H}$ NMR spectra of 1 in DMSO- $\mathrm{d}_{6}$ in the absence (a) and in the presence (b) of 0.5 , (c) 1.0 , (d) 1.5 equivalent of $\mathrm{AcO}^{-}$.

\section{Conclusion}

In conclusion, 1 has been developed as a novel colorimetric receptor for $\mathrm{AcO}^{-}$anion. It has been demonstrated that the receptor can bind anions in a 1:1 stoichiometry (except for $\mathrm{F}^{-}$) with obvious colorimetric changes, where the complex had been formed between $\mathbf{1}$ and $\mathrm{AcO}^{-}$by hydrogen bonding as proved by ${ }^{1} \mathrm{H}$ NMR titration. 


\section{Acknowledgement}

This work was supported by the projects 20371028, 20671052 from the National Natural Science Foundation of China.

\section{References}

1. Miao, R.; Zheng, Q. Y.; Chen, C. F.; Huang, Z. T.; Tetrahedron Lett. 2005, 46, 2155.

2. Buhlmann, P.; Pretsch, E.; Bakker, E.; Chem. Rev. 1998, 98, 1593.

3. Kral, V.; Sessier, J. L.; Tetrahedron 1995, 51, 539.

4. Kavauierators, K.; Carbtree, R. H.; Chem. Commun. 1999, 20 , 2109.

5. Hubner, G. M.; Glaser, J.; Sell, C.; Angew Chem. Int. Ed. Engl. 1999, 38, 383.

6. Yamagchi, S.; Akiyama, S.; Tamao, K.; J. Am. Chem. Soc. 1999, 121, 10438.

7. Gunnlaugsson, T.; Davis, A. P.; O’Brien, J. E.; Glynn, M.; Org. Lett. 2002, 4, 2449.

8. Hossain, M. A.; Llinares, J. M.; Powell, D.; Bowman-James, K.; Inorg. Chem. 2001, 40, 2936.
9. Szumna, A.; Jurczak, J.; Eur. J. Org. Chem. 2001, 4031.

10. Beer, P. D.; Szemes, F.; J. Am. Chem. Soc. 1997, 119, 11864.

11. Yu, X. D.; Lin,H.; Cai, Z. S.; Lin, H. K.; Tetrahedron Lett. 2007, 48,8615 .

12. Lin, Z. H.; Ou, S. J.; Duan, C. Y.; Zhang, B. G.; Bai, Z. P.; Chem. Commun. 2006, 624.

13. Amendola, V.; Gomez, D. E.; Fabbrizzi,L.; Licchelli, M.; Acc. Chem. Res. 2006, 343.

14. Bonizzoni, M.; Fabbrizzi, L.; Taglietti, A.; Tiengo, F.; Eur. J. Org. Chem. 2006, 3567.

15. Job, A.; Liebigs Ann. Chem. 1928, 9, 113.

16. Liu, Y.; You, C. C.; Zhang, H. Y.; Supramolecular Chemistry, Nankai University Press, Tianjin. 2001.

17. Valeur, B.; Pouget, J.; Bourson, J.; Kaschke, M.; Ernsting, N. P.; J. Phys. Chem. 1992, 96, 6545.

18. Pan, B.; Gao, F.; He, R.; Cui, D.; Zhang, Y.; J. Colloid Interface Sci. 2006, 297, 151.

19. Sessler, J. L.; Gale, P.; Cho, W. S.; Anion Receptor Chemistry, The Royal Society of Chemistry. 2006.

Received: October 12, 2008 Web Release Date: December 15, 2009 